\title{
Program Development for Primary School Teachers' Critical Thinking
}

\author{
Waraporn Boonjeam ${ }^{1}$, Kowat Tesaputa ${ }^{1} \&$ Anan Sri-ampai ${ }^{1}$ \\ ${ }^{1}$ Faculty of Education, Mahasarakham University, Mahasarakham, Thailand \\ Correspondence: Waraporn Boonjeam, Surin Primary Education Service Area Office 2, Surin, Thailand. Tel: \\ 66-4260-8156. E-mail: twb919@hotmail.com
}

Received: August 11, 2016

doi:10.5539/ies.v10n2p131

\author{
Accepted: September 15, 2016 \\ Online Published: January 30, 2017 \\ URL: http://dx.doi.org/10.5539/ies.v10n2p131
}

\begin{abstract}
The objectives of this research were: 1) to study the elements and indicators of primary school teachers' critical thinking, 2) to study current situation, desirable situation, development technique, and need for developing the primary school teachers' critical thinking, 3 ) to develop the program for developing the primary school teachers' critical thinking, and 4) to study the findings of usage in development program for primary school teachers' critical thinking by using Research and Development. The samples were 384 primary school teachers, and 34 volunteered teachers to participate in development by using questionnaire, evaluation form, and tests. The statistic using for data analysis included the percentage, mean, standard deviation, modified priority needs index ( $\left.\mathrm{PNI}_{\text {modified }}\right)$, and t-test. The research findings found that: 1) the elements and indicators of primary school teachers' critical thinking consisted of 3 elements and 12 indicators of critical thinking ability, and 6 elements and 24 indicators of critical thinking disposition, 2) the current situation of primary school teachers' critical thinking was in "High" level, for desirable situation, it was in "The Highest" level, 3) the development program, consisted of: the principles, objectives, contents, and development activities included 4 Parts, Part 1: the readiness preparation, Part 2: training, Part 3: integration with work practice, and Part 4: posttest, and measurement and evaluation. 4 . The posttest score was significantly higher than the pretest score at .01 level.
\end{abstract}

Keywords: critical thinking, primary school teachers, development program

\section{Introduction}

The present global society is the period of economic knowledge based. Human beings had to live among various information technology and news which could be easily and quickly accessed. Consequently, the perception of different incidences was occurred throughout the time from reading, listening, and watching. Therefore, human development for their good reading skill leading to thinking process in dimensions of analytical thinking, synthetic thinking, or critical thinking, it was necessary for developing the human resources' quality into high potentiality in every aspect, and readiness for creative adjustment as well as collaboration in global stage. It was congruent with conceptual framework for learning in the 21 st century. Children and youth learned the learning and innovation skills or $3 \mathrm{R}$ and $4 \mathrm{C}$. The $3 \mathrm{R}$ consisted of Reading, Writing, and Arithmetic. The $4 \mathrm{C}$ consisted of Critical thinking, Communication, Collaboration, and Creativity.

Thinking was working process of one's brain as an important instrument for learning, considering, and analyzing what would be good or bad. Many educators specified the significance of thinking ability that "Every level of learning process had to be emphasized on students' training for critical thinking." "Most of content provided in classroom, and memorizing from textbooks caused the students to lack of experience, critical thinking, experience synthesizing for higher wisdom" (Wasi, 1994, pp. 20-24). "Globalization trend brought both of good and bad things." Therefore, the instructional process should help students to obtain knowledge, thinking, right thought, and learn how to adjust themselves" (Kettat, 2002, pp. 1-2). Specifically, the Critical Thinking was very important since it was purposeful thinking using for considering and judging carefully with the occurred information or situation based on one's own knowledge, thought, and experience in exploring the evidences carefully in order to conclude logically. As a result, critical thinking was self-worth since it was necessary condition for educational management like symbol of be educated persons (Norris, 1985, pp. 21-26; Bodi, 1988, p. 89).

The recent problem of Thai Educational Management, many students' weak points were: the lack of thinking or they preferred not to think, they lacked of imagination and inspiration of themselves. Consequently, their lives 
were aimless. They could not tell what they wanted in their future. They let the social trend lead them without direction. It was supported by Charoenwongsak's (2002) statement that the greatest problem of Thai Educational Management, was the inability to make students to think. Thai students were not thoughtful persons. They did not like to ask. But, they liked to take their note, and were able to listen to lecture throughout semester without even one question. It was congruent with assessment findings of Office of Educational National Education Standard and Quality Assessment (OES) in basic education level. For major issue, students had weak point in critical thinking and synthetic thinking. It was supported by Program for International Student Assessment: PISA, found that their critical thinking and synthetic thinking abilities were in needed to be improved quickly. Even the graduates from the top institutions in Thailand, they could not think.

There were 3 important issues in improvement of school learning and teaching with quality: 1) the selection of Right People to be teachers (quality of educational system was not higher than the teachers' quality), 2) the development for quality teachers (improvement of students' quality was caused by instructional improvement only), and 3) the system management and goal setting for supporting the assurance that every child would be able to gain benefit from the best educational management. The best quality system would be caused by improvement of every student' standard level only (Office of The Education Council, 2009, pp. 21-23). Furthermore, the important persons to help educational management to accomplish goal, were teachers because they could directly apply the curriculum with their students.

The learning management for thinking was an important thing to be developed by in every class of students especially in primary students by the teachers. (Hilgard, 1962, p. 36; Charoenwongsak, 2012, p. 63; Kammanee, 2001, p. 5) However, according to the study of synthetic research studies in critical thinking from both of in our country and foreign countries, found that most of them aimed to develop the high school students' critical thinking and university students, and enhance the students' critical thinking only. For teacher development aimed to develop the learning management with emphasis on critical thinking by using the instructional model, was not focused on teachers' critical thinking development. Moreover, it was only the specific development activity for short period of time which was not systematic plan or activity, without continuous supervision, following up, and evaluation to be relevant to the thinking skill development which the regular and systematic training were required.

The development for primary school teachers to have knowledge, competency, and good attitude towards learning management with emphasis on critical thinking as well as self-development, in order to be persons with critical thinking skill for applying in learning management efficiently. As Cave's (1993, pp. 278-300) findings in "Teachers' Behavior and Disposition on Students' Critical Thinking," found that teachers with high level of critical thinking often taught their students through various teaching methods, changed the learning activities differently, provided the higher order thinking skills as well as activities enhancing the application skill. For the teachers being evaluated as low critical thinking persons, would teach by teacher-centered. Therefore, ideally, the teachers were persons being responsible for providing the experience management to help their students to learn based on educational management objective. They played important role in developing their students' critical thinking especially the role of role model for their students. Consequently, the teachers might be able to do their duties best in developing their students' critical thinking. So, it was necessary for them to obtain knowledge in both of critical thinking, and critical thinker as well (Washington, 1987; Gonzales-Rubio, 1988).

\section{Purposes}

1) To study the elements and indicators of primary school teachers' critical thinking.

2) To study the current situation, desirable situation, development technique, and need for developing the primary school teachers' critical thinking.

3) To develop the development program for primary school teachers' critical thinking.

4) To study the usage findings of development program for primary school teachers' critical thinking.

\section{Methodology}

The development of development program for primary school teachers' critical thinking, the research was conducted by Research and Development: R \& D including 4 phases as follows: 
Table 1. Research phases, methodology, instruments, and findings of program development for primary school teachers' critical thinking

\begin{tabular}{|c|c|c|c|}
\hline Phases & Methodology & Instruments & Findings \\
\hline $\begin{array}{l}\text { Phase 1: } \\
\text { the elements and } \\
\text { indicators } \\
\text { primary } \\
\text { teachers' } \\
\text { thinking }\end{array}$ & $\begin{array}{l}\text { 1. Principles, approaches, and } \\
\text { related theories and literatures } \\
\text { were studied for synthesizing } \\
\text { into elements and indicators of } \\
\text { primary school teachers' } \\
\text { critical thinking. } \\
\text { 2. The propriety of elements } \\
\text { and indicators in primary } \\
\text { school teachers critical } \\
\text { thinking was verified by } 7 \\
\text { experts. }\end{array}$ & $\begin{array}{l}\text { The Evaluation } \\
\text { Form of propriety } \\
\text { of elements and } \\
\text { indicators. }\end{array}$ & $\begin{array}{l}\text { The elements and indicators of primary school teachers' } \\
\text { critical thinking were obtained. }\end{array}$ \\
\hline $\begin{array}{l}\text { Phase 2: Studying } \\
\text { current situation, } \\
\text { desirable situation, } \\
\text { development } \\
\text { technique, and need } \\
\text { for developing } \\
\text { the primary school } \\
\text { teachers' } \\
\text { critical thinking }\end{array}$ & $\begin{array}{l}\text { 1. The elements and indicators } \\
\text { from phase } 1 \text {, were used as } \\
\text { conceptual framework in } \\
\text { constructing the questionnaire } \\
\text { asking current situation and } \\
\text { need for developing primary } \\
\text { school teachers critical } \\
\text { thinking. } \\
2 . \text { The questionnaires were } \\
\text { administered with samples as } \\
384 \text { primary school teachers } \\
\text { selected by multi stage } \\
\text { sampling. }\end{array}$ & $\begin{array}{l}\text { The questionnaire } \\
\text { asking current } \\
\text { situation and need } \\
\text { for developing the } \\
\text { primary school } \\
\text { teachers critical } \\
\text { thinking. }\end{array}$ & $\begin{array}{l}\text { The current situation, desirable situation, development } \\
\text { technique, and need for developing the primary school } \\
\text { teachers' critical thinking. }\end{array}$ \\
\hline $\begin{array}{l}\text { Phase } \\
\text { Developing } \\
\text { the program for } \\
\text { developing } \\
\text { primary the } \\
\text { teachers' critical } \\
\text { thinking }\end{array}$ & $\begin{array}{l}\text { 1. The principles, approaches, } \\
\text { and related theories and } \\
\text { literatures for synthesizing the } \\
\text { framework in developing the } \\
\text { program, were studied. } \\
\text { 2. The study and in-depth } \\
\text { interview were provided for } \\
\text { school administrators and } \\
\text { teachers as pioneers of } \\
\text { thinkers. } \\
\text { 3. The development program } \\
\text { for primary school teachers' } \\
\text { critical thinking, was outlined. } \\
\text { In addition, the handbook of } \\
\text { program development for } \\
\text { primary school teachers' } \\
\text { critical thinking, was also } \\
\text { outlined. } \\
\text { 4. The propriety and feasibility } \\
\text { of tentative program and } \\
\text { handbook of development } \\
\text { program for developing the } \\
\text { primary school teachers' } \\
\text { critical thinking, were } \\
\text { investigated. } \\
\text { 5. The program and handbook } \\
\text { of development program for } \\
\text { primary school teachers' } \\
\text { critical thinking, were revised }\end{array}$ & $\begin{array}{l}\text { The } \\
\text { Interview Form. } \\
\text { The Evaluative } \\
\text { Form of propriety } \\
\text { and feasibility of } \\
\text { program, and } \\
\text { handbook of } \\
\text { program. }\end{array}$ & $\begin{array}{l}\text { 1. The development program for developing primary } \\
\text { school teachers' critical thinking, was obtained. } \\
\text { 2. The handbook of development program for primary } \\
\text { school teachers' critical thinking, was established. }\end{array}$ \\
\hline
\end{tabular}




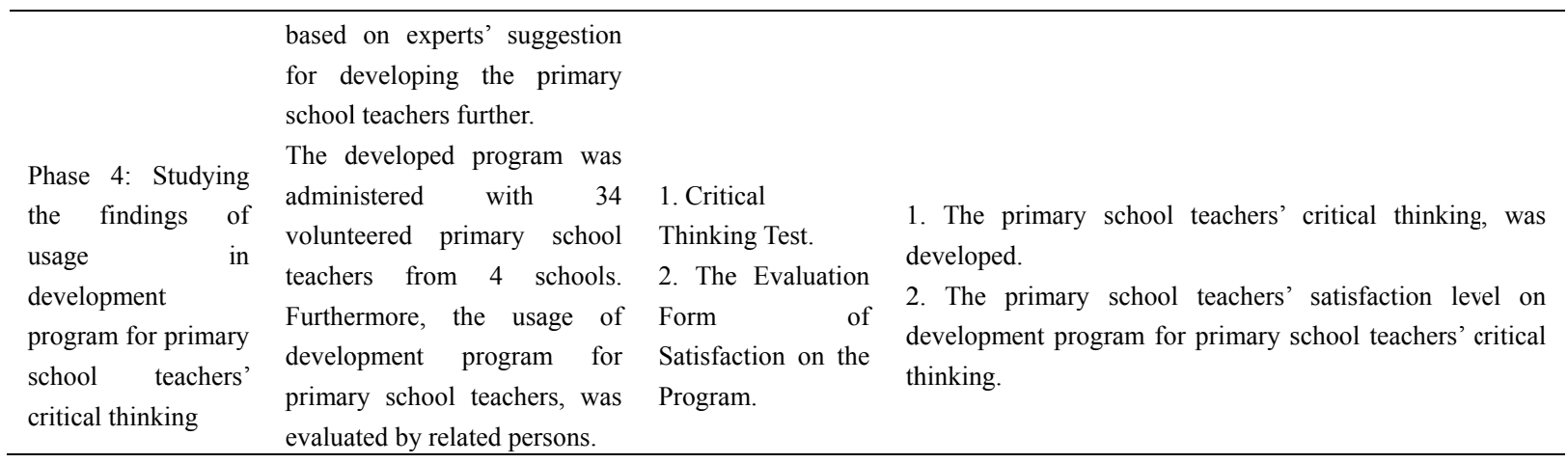

\section{Results}

I) The findings of elements and indicators in primary school teachers' critical thinking:

The experts viewed that the elements and indicators, in overall, the Propriety was in "The Highest" level. For each aspect, the propriety was ranged from "High" to "The Highest" level. The elements and indicators were obtained as follows: 1) the abilities of primary school teachers in critical thinking consisted of 3 elements and 12 indicators, 2) the disposition of primary school teachers with critical thinking, consisted of 6 elements and 24 indicators.

II) The current situation, desirable situation, development technique, and need for developing the primary school teachers' critical thinking, found that the current situation of primary school teachers' critical thinking ability, in overall, was in "High" level. Considering each item, it was in "High" level. For desirable situation of primary school teachers" critical thinking ability, in overall, it was in "The Highest" level. Considering each item, it was in "The Highest" level. For the disposition of primary school teachers with critical thinking, in overall, was in "The Highest" level. Besides, considering each item, it was in "The Highest" level. Moreover, the needs for developing the primary school teachers' critical thinking, in overall, ranked into the orders including: the critical thinking, and the disposition of primary school teachers with critical thinking. It was found that the development technique of primary school teachers' critical thinking consisted of the self-study, participatory training, field trip study, integration with work practice, and participatory following up.

III) The development of development program of primary school teachers' critical thinking.

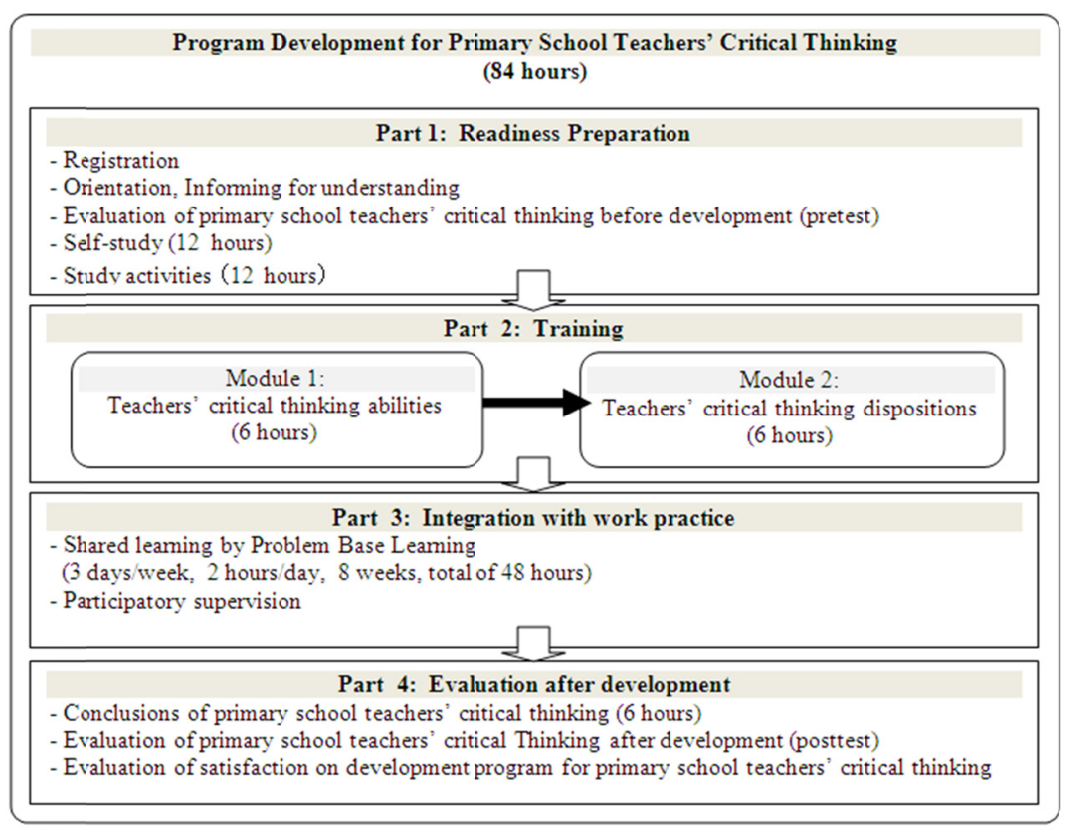

Figure 1. Development program for primary school teachers' critical thinking 
The development program for primary school teachers' critical thinking, consisted of 2 parts: 1) the development program for primary school teachers' critical thinking, and 2) the handbook of program use. The program elements were:1) the principles, 2) objectives, 3) contents, 4) development activities, and 5) measurement and evaluation. The details covered elements of primary school teachers' critical thinking including 2 Modules of activities, Module 1: primary school teachers' critical thinking ability, and Module 2: disposition of primary school teachers with critical thinking. The approaches for establishing the documents in developing primary school teachers' critical thinking, were applied from Malcolm S Knowles' adult learning principle, and Bloom's learning steps by presenting the adult's learning process, and learning steps respectively, in the same pattern: 1) the introduction: former experience and the potential new one was reviewed by creating the awareness and significance of content issues to be learned, 2) basic knowledge: comprehension was developed for lesson introduction, 3) doing: when the knowledge, content, and theories were obtained by self-study, the obtained knowledge and skill were applied in activities and exercises regularly for reviewing and understanding the content as well as principles for work practice, 4) lesson conclusion: the lesson content in program, was summarized, 5) measurement and evaluation: the content knowledge from self-study, was tested. The implementation of development for primary school teachers' critical thinking, development process was specified with 4 parts, Part 1: readiness preparation, Part 2: training, Part 3: integration with work practice, and Part 4: evaluation after development.

IV) The evaluative findings of development program usage for primary school teachers' critical thinking.

The primary school teachers who volunteered to development program, in overall, before development (pretest), the Mean was $=56.41$ out of 108 points of full score, or $52.23 \%$. For the score after development (posttest), the Mean was $=92.06$ out of 108 points of full score, or $85.24 \%$. When the Mean differences were tested, found that the posttest scores were significantly higher than the pretest at .01 level.

In addition, every person could pass the criterion of $75 \%$.

The primary school teachers who volunteered to development program, had satisfaction on development program for primary school teachers' critical thinking, in overall, in "The Highest" level. Considering each aspect, found that The Highest level of Mean in satisfaction was in the development activities. The second order included the training place and facility, and the content and document respectively.

\section{Discussion}

The findings of elements and indicators in primary school teachers' critical thinking:

The abilities of primary school teachers' critical thinking consisted of 3 abilities, 12 indicators. The experts viewed that the elements and indicators of critical thinking ability, in overall, the propriety was in "The Highest" level. For each aspect, the propriety was ranged from "High" level to "The Highest" level. It was due to the theories, approaches, and related research literatures of critical thinking, were synthesized systematically. It was supported by the educators and psychologists of critical thinking including: 1) Four indicators of Clarification: 1.1) the precise and challenging in asking and answering, 1.2) the inferential analysis, 1.3) the precise specification of problem issues, and 1.4) the explanation for definition of problem. It was supported by Dressel and Mayhew (1957); Norris \& Ennis (1989), and Ponkul (2011, p. 15) 2) Abilities in considering to judge the data for 5 indicators including: 2.1 ) the consideration in reliability of data by observation, 2.2) the consideration in reliability of data by classification, 2.3) the consideration in reliability of data by comparison, 2.4) the consideration in reliability of data by ranking, and 2.5) the consideration in reliability of data by differences of opinion. It was supported by Dressel and Mayhew (1957), Norris and Ennis (1989), Payutto (1989), Kowtrakool (2009, pp. 210-211), Kammanee (2010, p. 155), Kongsong (2010, p. 56), and Ponkul (2011, p. 15), and 3) Three indicators of Inference including: 3.1) Deduction, 3.2) Induction, 3.3) Reasonable Conclusion of alternatives. It was supported by Dressel and Mayhew (1957), Watson and Glaser (1964, p. 2), Norris and Ennis (1989); Payutto (1989), and Ponkul (2011, p. 15).

The Disposition of primary school teachers with critical thinking consisted of 6 elements and 24 indicators. The experts viewed that the elements of primary school teachers' critical thinking, in overall and each aspect, the propriety level was in "The Highest" level. Since the researcher systematically synthesized the theories, approaches, and research studies in critical thinking. It was supported by educators and psychologists including: 1) seven indicators of Open minded persons: 1.1) acceptance in different opinion from one's own, 1.2) various aspects viewpoint, 1.3) sensitivity for others' feeling and understanding the others, 1.4) searching for others' good thinking, 1.5) self-control without bias, 1.6) humbleness without egocentric, and 1.7) changing one's own thought in case of sufficient reasons. It was supported by Ennis (1987), Alfaro-Lefevre (1995), Potisook and Kongsong (2001), Raines and Ewing (2006), CCDI (2008), Bassham et al. (2011), and Charoenwongsak (2012) 
2) Three indicators of Analysts including: 2.1) the ability in data analysis, and comprehension in real problem situation, 2.2) the ability in reasoning based on situation, and 2.3) the prediction for future incidence. It was supported by Alfaro-Lefevre (1995); Potisook and Kongsong (2001); Wade and Tavris (2002); Kammanee (2005); CCDI (2008), and Bassham et al. (2011), 3) Three indicators of Truth-seeking persons including: 3.1) the enthusiasm in knowledge searching, 3.2) seeking for the best truth although it might not be relevant to the others, and 3.3) thinking for questioning regularly. It was congruent with Potisook and Kongsong (2001); Wade and Tavris (2002); Raines and Ewing (2006); CCDI (2008), and Charoenwongsak (2012). 4) Three indicators of persons with Cognitive Maturity including: 4.1) carefulness, 4.2) reasoning, and 4.3) critical thinking ability in the obstacle situation. It was supported by Ennis (1987); Alfaro-Lefevre (1995); Potisook and Kongsong (2001); Wade \& Tavris (2002); Kammanee (2005); Raines \& Ewing (2006); CCDI (2008); Bassham et al. (2011), and Charoenwongsak (2012) 5) Five indicators of Systematic thinkers including: 5.1) the holistic comprehension, 5.2) problem solving ability in complex problems, 5.3) note taking for complex and important issues, 5.4) working arrangement step by step with intensive detail, and 5.5) learning how to plan for precise knowledge application. It was congruent with Alfaro-Lefevre (1995); Potisook and Kongsong (2001); Raines and Ewing (2006), and CCDI (2008), and 6) Three indicators of Self-confidence persons including: 6.1) confidence in one's own reasoning skill, 6.2) firmness without unstable mind, and 6.3) courage to face with the others' prejudice. It was supported by Alfaro-Lefevre (1995); Raines and Ewing (2006); CCDI (2008), and Charoenwongsak (2012).

The current situation and desirable situation of primary school teachers' critical thinking, found that the current situation of primary school teachers' critical thinking ability, in overall, was in "High" level. Considering each item, it was in "The Highest" level. For desirable situation of primary school teachers' critical thinking ability, found that, in overall, it was in "The Highest" level. In addition, considering each item, it was in "The Highest" level. It might be because the former development was a short period one. Most of them aimed to teach how to think or technique for enhancing the students' thinking. But, there were no programs or development for primary school teachers' critical thinking directly. It was congruent with Sinlarat's (2001, p. 7) statement that the past implementation of teachers development in learning management for enhancing the thinking skill, was not performed continuously. It was repetitive without continuous development process. It was lacked of following up and evaluation systems. It was supported by Lewis (2012, pp. 56-58) study in critical thinking habit of agricultural teachers in Tennessee, found that the critical thinking was a major factor for leaders in agriculture. Although there were extensive studies and development in students' critical thinking, there was little number of study in implementing the development for teachers' critical thinking.

The findings of development program for primary school teachers' critical thinking, consisted of 2 parts: 1) the development program for primary school teachers' critical thinking, and 2) the handbook of program usage including the components of program: 1) the principles, 2) objectives, 3) contents, 4) development activities, and 5) measurement and evaluation. Malcolm S. Knowles' adult learning principles and Bloom's learning steps, were applied by presentation based on the adults' learning process as well as learning steps in sequence and the same pattern: 1) the introduction, 2) basic knowledge, 3) action, 4) lesson conclusion, and 5) measurement and evaluation by using 4 development parts, Part 1: readiness preparation, Part 2: training, Part 3: integration with work practice, and Part 4: evaluation after development. It was congruent with Kijrungrueng's (2010) study in "Development of Teaching Model by using the Case Study in Science of Instruction for enhancing the Teaching Profession Students through PCSSC Model," consisted of 4 elements: the principles, objectives, instructional process, and conditions for using the instructional model. The instructional process included 5 steps as follows: the Preparation, Case Groups, Selection of Solutions, Experience Sharing with Groups, and Construction for New Knowledge. Furthermore, it was congruent with Nambandit's (2013) study in "Teachers Development Model of Teaching Process for Critical Thinking in Small Sized Schools, under jurisdiction of The Office of Mahsarakam Primary Educational Service Area 1," found that the teachers development model in teaching process for critical thinking in small sized schools, consisted of 4 major parts: the principles, objectives, techniques, and measurement and evaluation.

The primary school teachers who volunteered to participate in development, had pretest critical thinking, in overall, in "Good" level. Considering each aspect, found that the disposition of primary school teachers with critical thinking ability, was in "Fair" level. For the posttest, the critical thinking, in overall, every aspect was in "Very Good" level. It was the outcomes of critical thinking development which was congruent with Tangkaboot's (2009) study in "Development of Mixed Instructional Design Model by using Mind Map," the posttest Mean score of critical thinking, was significantly higher than the pretest at .01 level. It was congruent with Kijrungrueng's (2010) study in "Development of Teaching Model by using Case Study in Instructional Science for enhancing Teaching Profession Students' Critical Thinking Ability," the research findings found that 
the teaching profession students' posttest critical thinking ability, was significantly higher than the pretest at .05 level.

\section{References}

Alfaro-Lefevre, R. (1995). Critical Thinking in Nursing: A Practical Approach. Philadelphia: Saunders.

Bassham, G., Irwin, W., Nardone, H., \& Wallace, J. M. (2011). Critical Thinking. New York: McGraw Hill.

Bodi, S. (1988). Critical Thinking and Bibliographic Instruction: The Relationship. The Journal of Academic Librarianship, 14, 150-153.

California Critical Thinking Dispositions Inventory. (2008). Critical Thinking. http://aare.edu.au/01 pap/kon01173.htm

Cave, L. M. (1993). The Relationship of teacher Behaviors and Characteristics to Critical Thinking Skills Among Middle-Level Student (Doctor's thesis, Oregon State University).

Charoenwongsak, C. (2002). Thinkers'Map. Bangkok: Success Media.

Charoenwongsak, C. (2012). Critical Thinking (9th ed.). Bangkok: Success Media.

Dressel, P. L., \& Mayhew, L. B. (1957). General Education: Exploration in Evaluation (2nd ed.). Washington D.C.: American Council on Education.

Ennis, R. H. (1987). A taxonomy of critical thinking dispositions and abilities. Teaching thinking skills: Theory and Practice. J. B. Baron, \& R. J. Sternberg (Eds.). New York: W. H. Freeman.

Gonzales-Rubio, V. C. (1988). An investigation of the relationships between secondary teachers' instruction of critical thinking skills and their students' perceptions of those skills (Ed.D, Southern Illinois University at Edwardsville).

Hilgard, E. R. (1962). Introduction to Psychology. New York: Harcourt, Brace \& World.

Kammanee, T. (2001). Thinking Technology. Bangkok: The Master Group Management.

Kammanee, T. (2005). Instructional Model: Various Alternatives. Bangkok: Chulalongkorn University Printing.

Kammanee, T. (2010). Science of Teaching in Body of Knowledge for Efficient Learning Process Management. (13th ed.). Bangkok: Chulalongkorn University Printing.

Kettat, S. (2002). From the Past and Present to Future of Thai Educational Reform: Into Society of Wisdom and Learning. Bangkok: Ladprao Kurusapa.

Kijrungroeng, P. (2010). Development of Teaching Model by using Case Study in Instructional Science for enhancing Teaching Profession Students' Critical Thinking Ability (Doctor of Education thesis in Curriculum and Instruction, Department of Curriculum and Teaching Technique, Silpakon University).

Kongsong, S. (2010). Program Development for enhancing Critical Thinking for Gifted Students in Grade 4-5 (Doctor of Education thesis, Srinakarintarawirote University).

Kowtrakool, S. (2009). Educational Psychology (8th ed.). Bangkok: Faculty of Education, Chulalongkorn University.

Lewis, C. Y. (2012). Critical thinking dispositions of Tennessee agriculture teachers (Unpublished M.S.). Tennessee State University, Ann Arbor.

Nambandit, C. (2003). Teachers Development Model for Critical Thinking Instructional Process in Small Sized Schools, under The Office of Mahasarakam Primary Educational Service Area 1 (Doctor of Education thesis in Educational Administration and Management, Mahasarakam Rajabhat University).

Norris, S. P. (1985). Synthesis of Research on Critical Thinking. The Educational Leadership, May, 40-45.

Norris, S. P., \& Ennis, R. H. (1989). Evaluating critical thinking. California: Midment Publications Critical Thinking Press.

Office of the Education Council. (2009). How to be World Class Quality School System into Leading Quality School. Bangkok: Prigwan Graphic.

Payutto, P. (1989). Universal Science on Thai Wisdom Foundation. Bangkok: Kasetsat University.

Ponkul, C. (2011). Thinking Process Teaching: Theory and Application. Bangkok: V Print.

Potisook, U., \& Kongsong, S. (2001). Thinker Development: Handbook of Educational Management for 
Talented Persons with Higher Order of Thinking. Bangkok: National Center for developing the Talented Persons.

Raines, C., \& Ewing, L. (2006). The art of connecting: How to overcome different, build rapport, and communicate effectively with anyone. Upper Saddle River: Pearson Education.

Sinlarat, P. (2001). Knowledge and Ethics: Articles of Ethics, Morality, and Education. Bangkok: Chulalongkorn University.

Tangkaboot, T. (2009). Model Development of Mixed Instructional Model by using Mind Map for enhancing Undergraduates' Critical Thinking (Doctor of Education thesis in Educational Technology and Media, Department of Curriculum and Instruction and Educational Technology, Chulalongkorn University).

Wade, C., \& Tavris, C. (2002). Invitation to psychology (2nd ed.). Upper Saddle River, NJ: Prentice Hall.

Washington, N. L. (1987). Schooling and the struggle to teach for critical thinking: A case study of implementation (Ph.D. Washington University).

Wasi, P. (1994). Educational Development in Future in Guidelines for Future Educational Development. Bangkok: Office of The National Education Commission.

Watson, G., \& Glaser, E. M. (1964). Watson-Glaser Critical Thinking Appraisal Manual. New York: Harcourt, Brace and World.

\section{Copyrights}

Copyright for this article is retained by the author(s), with first publication rights granted to the journal.

This is an open-access article distributed under the terms and conditions of the Creative Commons Attribution license (http://creativecommons.org/licenses/by/4.0/). 